\title{
HUBUNGAN KEPEMIMPINAN DENGAN MOTIVASI KERJA PEGAWAI DI BAGIAN ASISTEN PEMERINTAHAN KANTOR GUBERNUR SUMATERA SELATAN
}

\author{
Antartila Rezki Aziz ${ }^{1}$ \\ 1) Sekolah Tinggi Ilmu Administrasi (STIA) Satya Negara Palembang \\ Email : Antartilarezkiaziz@gmail.com
}

\begin{abstract}
The purpose of this research is to see the connection between leadership and work motivation of employee at Government Assistant Office of the Governor of South Sumatra. The population are 89 and the sample are 55 which taken using Cohcran formula. The instrument of this research is question with Likert scale models that had tested for validity and reliability. Data analyzed using product moment correlation formula. The result of this research there are meaningful relationship between leadership and work motivation of employee Government Assistant Office of the Governor of South Sumatra.
\end{abstract}

Key word: leadership and work motivation of employee

\section{PENDAHULUAN}

Secara sederhana organisasi dapat diartikan sebagai wadah bagi orang-orang untuk berkumpul dan bekerjasama dalam mencapai tujuan tertentu. Organisasi terbentuk karena dipenganuhi oleh beberapa aspek seperti struktur, tujuan, saling berhubungan satu bagian dengan bagian lain, pengelolaan dan kepemimpinan. Setiap organisasi mempunyai suatu tujuan yang telah direncanakan bersama dan harus dilaksanakan secara bersama oleh orang-orang yang terlibat dalam organisasi tersebut. Orangorang yang terlibat dalam organisasi biasanya ada yang disebut pimpinan dan ada juga yang disebut bawahan atau pegawai.

Pada umumnya, pemimpin terdiri dari satu orang yang membawahi beberapa pegawai. Pegawai menupakan salah satu bagian dari organisasi yang menjalankan aktivitas di organisasi tersebut, baik sebagai pembuat perencanaan, maupun sebagai pelaksana dari kegiatan organisasi. Tercapai atau tidaknya tujuan organisasi yang telah ditetapkan tergantung kepada personil yang ada dalam organisasi, antar personil harus memiliki kerjasama yang baik demi pencapaian tujuan tersebut.

Untuk mencapai tujuan organisasi, pegawai harus memiliki motivasi kerja yang tinggi dalam melaksanakan tugas dan tanggung jawabnya. Motivasi kerja yang tinggi merupakan salah satu faktor yang dapat mempengaruhi keberhasilan pelaksanaan suatu pekerjaan. Tanpa adanya motivasi kerja yang tinggi tentunya pegawai tidak akan melakukan pekerjaannya dengan maksimal sehingga pencapaian tujuan organisasi pun kurang optimal.

Berdasarkan pengamatan secara informal di Kantor Gebernur Sumatera Selatan, terdapat 
masalah yang mengindikasikan bahwa masih rendahnya motivasi kerja para pegawai dalam melaksanakan tugas dan tanggung jawabnya. Hal ini dapat dilihat dari beberapa fenomena seperti: (1) masih ada pegawai yang menunda-nunda pelaksanaan tugasnya dan masih terlihat santai, (2) sebagian pegawai kurang menyukai umpan balik dari pimpinan tentang keberhasilan ataupun kekurangan dari tugas yang telah dibuat, (3) sebagian pegawai minat kerjanya masih kurang dalam mengerjakan tugas, (4) masih banyak pegawai yang kurang inisiatif, terlihat sebagian pegawai hanya bekerja ketika ada perintah dari pimpinan saja.

Banyak faktor yang mempengaruhi motivasi kerja pegawai, salah satunya adalah kepemimpinan. Hal ini dinyatakan oleh Pasolong (2010:152) bahwa motivasi kerja dipengaruhi oleh dua faktor, yaitu faktor ekstern dan faktor intem. Faktor ekstern terdiri dari kepemimpinan, lingkungan kerja yang menyenangkan, komposisi yang memadai, adanya penghargaan terhadap prestasi, status dan tanggungjawab, serta peraturan yang berlaku.

Kepemimpinan sangatlah penting untuk menggerakkan suatu organisasi, terutama dalam menggerakkan pegawai agar bekerja dengan baik. Fenomena yang penulis temui di lapangan mengenai kepemimpinan adalah: (1) kurangnya petunjuk dan perhatian yang diberikan oleh pimpinan kepada bawahan dalam pelaksanaan tugas, (2) kurangnya pembinaan dan pegawasan pimpinan terhadap pegawai, (3) pimpinan jarang memberikan pujian kepada pegawai atas hasil kerja pegawai, sehingga pegawai merasa hasil kerjanya kurang dihargai oleh pimpinan. Melihat fenomenafenomena tersebut penulis tertatik untuk melakukan penelitian, dengan tujuan untuk melihat hubungan antara kepemimpinan dengan motivasi kerja pegawai di Bagian Asisten Pemerintahan Kantor Gubemur Sumatera Selatan.

\section{METODE PENELITIAN}

Jenis penelitian ini bersifat korelasional, yaitu menggambarkan tentang hubungan kepemimpinan dengan motivasi kerja pegawai. Populasi penelitian ini adalah selunuh pegawai di Bagian Asisten Pemerintahan Kantor Gubernur Sumatera Selatan yang berjumlah 89 orang. Besar sampel ditentukan menggunakan Stratified Proporsional Random Sampling sehingga diperoleh jumlah sampel sebanyak 55 orang. Instrumen penelitian ini adalah angket skala likert yang telah dilakukan uji validitas dan reliabilitasnya. Data dianalisis menggunakan rumus korelasi product moment.

\section{HASIL PENELITIAN}

Pengumpulan data variabel kepemimpinan (variabel $\mathrm{X}$ ) didapat dari penyebaran angket kepada 55 orang responden. Skor kepemimpinan yang diperoleh menyebar dari skor terendah 96 sampai skor tertinggi 150, sedangkan kategori skor minimal 1 dan skor maksimal 5. Dari hasil pengolahan data secara umum, maka untuk variabel kepemimpinan diperoleh skor mean (rata-rata) 130,23, median (nilai tengah) 130,53, modus (nilai yang sering muncul) 131,15, dan standar deviasi (persimpangan baku) 9,94. 
Berdasarkan hasil penelitian, variabel kepemimpinan mendapat angka ratarata $72,35 \%$ yang berada pada kategori cukup baik. Sedangkan untuk variabel motivasi kerja mendapat angka ratarata 83,03\% ini berada pada kategori tinggi. Artinya kedua variabel tersebut masih bisa ditingkatkan lagi agar dapat mencapaihasil yang maksimal. Rata-rata per indikator terlihat seperti Tabel 1.

Tabel 1.

Tingkat Capaian Per Indikator Kepemimpinan

\begin{tabular}{|c|c|c|c|c|}
\hline No & Indikator & Rata-Rata & $\begin{array}{c}\text { Tingkat } \\
\text { Capaian }\end{array}$ & Kategori \\
\hline 1 & Mempengaruhi & 3,70 & $74 \%$ & Cukup Baik \\
\hline 2 & Mengarahkan & 3,79 & $75,8 \%$ & Cukup Baik \\
\hline 3 & Memotivasi & 3,39 & $67,8 \%$ & Cukup Baik \\
\hline
\end{tabular}

Pengumpulan data variabel motivasi kerja pegawai (variabel $\mathrm{Y}$ ) didapat dari penyebaran angket kepada 55 orang responden. Skor motivasi kerja pegawai yang diperoleh menyebar dari skor terendah 101 sampai skor tertinggi 154, sedangkan kategori skor minimal 1 dan skor maksimal 5. Dari hasil pengolahan data secara umum, maka motivasi kerja pegawai diperoleh skor mean (ratarata) 137, median (nilai tengah) 138,4, modus (nilai yang sering muncul) 141,2, dan standar deviasi (persimpangan baku) 10,5.
Berdasarkan pengolahan data angket variabel motivasi kerja pegawai $(\mathrm{Y})$ dengan cara membandingkan skor rata-rata (mean) dengan skor maksimal dikali 100\%, maka nilai mean 137 dibagi dengan skor maksimal 165, maka diperoleh angka $0,8303 \times 100 \%=83,03 \%$. Hal ini berarti variabel motivasi kerja pegawai berada pada kategori "Tinggi” yaitu sebesar 83,03\% dari skor ideal.

Untuk mengetahui rata-rata setiap indikator dari motivasi kerja pegawai dapat dilihat pada Tabel 2.

Tabel 2.

Tingkat Capaian Per Indikator Motivasi Kerja Pegawai

\begin{tabular}{|c|c|c|c|c|}
\hline No & Indikator & Rata-Rata & $\begin{array}{c}\text { Tingkat } \\
\text { Capaian }\end{array}$ & Kategori \\
\hline 1 & Tanggung jawab & 4,17 & $83,4 \%$ & Tinggi \\
\hline 2 & Semangat kerja & 4,12 & $82,4 \%$ & Tinggi \\
\hline 3 & Disiplin Kerja & 4,14 & $82,8 \%$ & Tinggi \\
\hline 4 & $\begin{array}{c}\text { Kemandirian dalam } \\
\text { Bertindak }\end{array}$ & 3,97 & $79,4 \%$ & Cukup Tinggi \\
\hline
\end{tabular}




\section{PEMBAHASAN}

Berdasarkan hasil penelitian dapat disimpulkan bahwa kepemimpinan memiliki hubungan yang berarti dengan motivasi kerja pegawai pada taraf kepercayaan $99 \%$ dengan korelasi sebesar 0,37 dan keberartian korelasi 2,94 dengan menggunakan uji t. Untuk lebih jelasnya berikut akan diuraikan pembahasan dari masingmasing variabel.

\section{Motivasi Kerja Pegawai}

Berdasarkan hasil analisis data dan pengujian hipotesis diketahui bahwa motivasi kerja pegawai di bagian Asisten Pemerintahan Kantor Gubemur Sumatera Selatan berada pada kategori tinggi yaitu 83,03\% dari skor ideal. Melihat hasil dari pengolahan data tersebut, motivasi kerja pegawai masih bisa ditingkatkan agar menjadi lebih tinggi lagi.

Pimpinan sangat perlu memperhatikan motivasi kerja pegawai, karena motivasi kerja ini akan berdampak pada kemajuan suatu instansi. Rivai (2012:456) menyatakan bahwa pada dasarnya motivasi dapat memacu pegawai untuk bekerja keras sehingga mencapai tujuan. Hal ini meningkatkan produktivitas pegawai sehingga berpenganuh pada pencapaian tujuan organisasi.

Dilihat dari hasil pengolahan data penelitian per indikator motivasi kerja, indikator tanggung jawab mendapat rata-rata 4,17 atau berada pada kategori tinggi. Nilai rata-rata terendah adalah dalam hal melempar kesalahan kepada orang lain. Hal ini menggambarkan bahwa pegawai masih perlu ditingkatkan lagi rasa tanggung jawabnya, terutama dengan tidak melempar kesalahan kepada orang lain. Karena menurut Pasal 4 PP Tahun 1979 dalam Uno (2012:180) suatu tanggung jawab dalam melaksanakan tugas akan tercermin dar seseorang dalam melaksanakan tugasnya, saran satu cerminan yang dimaksud adalah tidak pemah melemparkan kesalahan yang dibuat kepada orang lain.

Untuk indikator semangat kerja juga berada pada kategori tinggi dengan rata-rata 4,12. Jika dilihat per sub indikator, kemampuan pegawai untuk menyelesaikan tugas dengan cepat dan baik masih mendapat rata-rata terendah. Untuk itu pegawai hendaknya lebih meningkatkan semangat kerjanya terutama dalam hal meyelesaikan tugas dengan cepat dan baik sehingga tujuan organisasi juga dapat dicapai sesuai target.

Selanjutnya, dalam hal disiplin kerja pegawai di Bagian Asisten Pemerintahan Kantor Gubernur Sumatera Selatan berada pada kategori tinggi dengan rata-rata 4,14. Akan tetapi dalam hal tepat waktu masih mendapat nilai rata-rata yang rendah dibandingkan sub indikator disiplin kerja lainnya. Agar menjadi lebih baik lagi, pegawai dapat meningkatkan disiplin kerjanya dalam hal ketepatan waktu dengan cara hadir, istirahat, dan keluar dari kantor sesuai dengan waktu yang telah ditetapkan. Dengan begitu pegawai dapat mengerjakan tugas dan tanggung jawabnya sesuai dengan waktu yang diberikan.

Sama halnya dengan ketiga indikator sebelumnya, untuk indikator kemandirian dalam bertindak juga berada pada kategori tinggi, rataratanya 3,97. Dalam hal kemandirian dalam bertindak pegawai masih mendapat nilai rendah untuk kreativitas. Untuk meningkatkannya, 
pegawai bisa saja memunculkan ide-ide baru dalam pelaksanaan tugasnya. Jika pegawai memiliki kreativitas yang tinggi, maka akan lebih mudah baginya untuk menyelesaikan pekerjaannya, sehingga tujuan organisasi dapat dicapai.

Jadi pada kesimpulannya motivasi kerja pegawai memiliki penganuh besar terhadap pencapaian tujuan. Karena jika pegawai memiliki motivasi kerja yang tinggi, maka produktivitas kerjanya juga tinggi, hal ini pun akan berimbas kepada prestasi kerjanya sehingga mempermudah pencapaian tujuan organisasi.

\section{Kepemimpinan}

Sejalan dengan penelitian dan pengolahan data terhadap motivasi kerja pegawai, maka untuk variabel kepemimpinan di Bagian Asisten Pemerintahan Kantor Gubernur Sumatera Selatan diperoleh hasil bahwa kepemimpinan mendapat presentase $72,35 \%$ dari skor ideal. Hal ini menunjukkan bahwa kepemimpinan masih berada pada kategori cukup baik, akan menjadi lebih baik jika penerapannya dioptimalkan lagi.

Kepemimpinan pada dasamya adalah kemampuan seseorang untuk mempengaruhi, memberi arahan, mendorong atau memotivasi orang lain baik individu maupun kelompok agar melakukan kegiatan untuk mencapai tujuan yang telah ditetapkan. Dengan adanya kepemimpinan dari atasan diharapkan semua personil di instansi yang dipimpinnya akan melaksanakan kegiatan dengan baik demi tercapainya tujuan bersama. Ini artinya, jika seorang pemimpin menguasai beberapa indikator kepemimpinan tersebut maka akan mudah baginya untuk melakukan tugasnya sebagai seorang pemimpin.

Melihat hasil penelitian yang menggambarkan bahwa kepemimpinan di Bagian Asisten Pemerintahan Kantor Gubemur Sumatera Selatan berada pada kategori baik, maka untuk hal ini agar lebih diperhatikan lagi oleh para pimpinan agar mau berusaha untuk meningkatkan kemampuannya, dengan harapan nantinya membawa pengaruh yang lebih baik lagi bagi instansi yang dipimpinnya.

Dilihat dari masing-masing indikator kepemimpinan, untuk indikator mempengaruhi memiliki rata-rata 3,70. Hal ini menandakan bahwa dalam hal mempengaruhi, pimpinan masih berada pada kategori cukup baik. Rata-rata terendah didapatkan oleh sub indikator melibatkan bawahan, artinya pimpinan masih kurang percaya untuk melibatkan pegawai dalam pekerjaannya. Untuk lebih baiknya diharapkan pimpinan dapat lebih melibatkan pegawai dalam berbagai kegiatan, karena sesuai dengan pendapat Kusman dan Rifma (2002:46) bahwa salah satu cara yang dapat dilakukan oleh pimpinan untuk mempengaruhi bawahannya adalah dengan melibatkan bawahan dalam proyek-proyek berarti, karena dengan begitu pegawai akan merasa keberadaannya lebih berarti di instansi tersebut.

Untuk indikator mengarahkan, pimpinan mendapatkan rata-rata 3,79 atau berada pada kategori cukup baik. Sub indikator dengan rata-rata terendah adalah memberikan koreksi. Hal ini menandakan bahwa pimpinan masih kurang memberikan koreksi terhadap pekerjaan yang dilakukan oleh pegawai. Sedangkan menurut 
Sagala (2009:58) salah satu kegiatan dari mengarahkan adalah memberikan koreksi agar setiap personal melakukan tugas-tugasnya secara efisien. Oleh karena itu, pimpinan sebaiknya lebih memperhatikan pegawai dengan memberikan koreksi terhadap hasil kerjanya dengan harapan pegawai dapat melakukan tugasnya lebih baik lagi.

Indikator dengan rata-rata terendah adalah indikator memotivasi, yaitu 3,39 juga berada pada kategori cukup baik. Dari hasil penelitian terlihat bahwa pimpinan masih belum maksimal dalam hal memotivasi bawahannya. Sub indikator dengan presentase terendah adalah dalam hal menumbuhkan rasa memiliki dan bersahabat. Untuk itu pimpinan diharapkan lebih sering bercengkrama dengan pegawai agar menimbulkan kebersamaan, baik dikantor maupun diluar kantor.

Pada hakikatnya, motivasi terbesar sebenamya memang berasal dari diri pegawai itu sendiri, akan tetapi motivasi dari luar pun sangat dibutuhkan oleh pegawai untuk mampu melaksanakan tugas dan tanggung jawabnya lebih baik lagi. Oleh karena itu, pimpinan tetap harus melakukan usaha maksimal untuk memotivasi para bawahannya.

Secara keseluruhan, pimpinan diharapkan meningkatkan kemampuan memimpinnya agar lebih mudah dalam mempengaruhi, mengarahkan, dan memotivasi pegawainya. Karena jika dilihat dari hasil pengolahan data penelitian, pimpinan belum bisa dikatakan maksimal dalam hal memimpin bawahannya, karena masih berada pada kategori cukup baik (72,35\% dari skorideal).
3. Hubungan Kepemimpinan dengan Motivasi Kerja Pegawai

Hasil pengujian hipotesis menunjukkan bahwa terdapat hubungan antara kepemimpinan dengan motivasi kerja pegawai yaitu dengan diperolehnya rhitung $=0,37>$ tabel $=0,345$ pada taraf kepercayaan 99\%. Pada keberartian korelasi juga terdapat hubungan yang signifikan antara kepemimpinan dengan motivasi kerja pegawai yaitu thitung $=2,94>\mathrm{t}$-tabel $=2,390$ pada taraf kepercayaan 99\%. Dengan demikian hipotesis yang diuji dapat diterima.

Hipotesis tersebut berbunyi adanya hubungan yang signifikan antara kepemimpinan dengan motivasi kerja pegawai. Hal ini menunjukkan bahwa salah satu faktor yang mempenganuhi motivasi kerja pegawai adalah kepemimpinan dari atasan. Hasil penelitian ini diperkuat dengan pendapat Pasolong (2010:152) yang menyatakan bahwa salah satu faktor yang mempenganuhi motivasi kerja adalah kepemimpinan dari atasan/pimpinan.

Berdasarkan uraian di atas dapat disimpulkan bahwa kepemimpinan sangat mempenganuhi motivasi kerja pegawai. Hasil penelitian ini memperlihatkan hubungan antara kepemimpinan dengan motivasi kerja pegawai, artinya semakin baik kepemimpinan seorang atasan maka motivasi kerja pegawai akan semakin tinggi, begitu pun sebaliknya. Sehingga kedua variabel ini harus sama-sama ditingkatkan agar menjadi lebih baik dan sesuai dengan apa yang diharapkan. 


\section{KESIMPULANDANSARAN}

Dilihat dari hasil penelitian dan pengujian hipotesis tentang hubungan kepemimpinan dengan motivasi kerja pegawai di Bagian Asisten Pemerintahan Kantor Gubernur Sumatera Selatan dapat diambil kesimpulan bahwa (1) kepemimpinan di Bagian Asisten Pemerintahan Kantor Gubemur Sumatera Selatan masih berada pada kategori cukup baik. Hal ini dapat dilihat dari perbandingan skor rata-rata (mean) 130,23 dengan skor maksimal 180 sehingga diperoleh persentase 72,35\% dari skor ideal, (2) motivasi kerja pegawai di Bagian Asisten Pemerintahan Kantor Gubemur Sumatera Selatan berada pada kategori tinggi. Terlihat dari perbandingan skor rata-rata (mean) 137 dengan skor maksimal 165 sehingga diperoleh presentase $83,03 \%$ dari skor ideal, (3) terdapat hubungan yang berarti antara kepemimpinan dengan motivasi kerja pegawai di Bagian Asisten Pemerintahan Kantor Gubernur Sumatera Selatan dimana thitung $=2,94>$ ttabel $=2,390$ pada taraf kepercayaan 99\%. Artinya kepemimpinan merupakan salah satu faktor yang mempengaruhi motivasi kerja pegawai dan motivasi kerja pegawai menentukan kepemimpinan di Bagian Asisten Pemerintahan Kantor Gubernur Sumatera Selatan dengan besarnya koefisien korelasi mitung $=0,37$ $>$ rtabel $=0,345$ pada taraf kepercayaan $99 \%$.

Berdasarkan kesimpulan di atas dapat dikemukakan saran-saran kepada beberapa pihak, diantaranya kepada: (1) pimpinan agar dapat meningkatkan kepemimpinannya dalam hal mempenganuhi, mengarahkan dan memotivasi pegawai agar lebih baik lagi, (2) pegawai agar menyadari tugas dan tanggung jawabnya, sehingga para pegawai selalu berusaha yang terbaik untuk pekerjaannya. Diharapkan juga kepada pegawai untuk dapat menimbulkan serta meningkatkan motivasi dari diri sendiri, selanjutnya kepada (3) peneliti selanjutnya agar dapat meneliti lebih dalam lagi tentang kepemimpinan dan motivasi kerja pegawai ini, karena masih banyak faktor lain yang mempengaruhi kepemimpinan dan motivasi kerja pegawai tersebut.

\section{DAFTAR PUSTAKA}

Kusman, Yuskal dan Rifma. 2002. Kepemimpinan Pendidikan (Bahan Ajar). Padang: UNP.

Pasolong, Harbani. 2010. Kepemimpinan Birokrasi. Bandung: Alfabeta.

Rivai,Veithzal dan Deddy Mulyadi. 2012. Kepemimpinan \& Perilaku Organisasi. Bandung: Raja GrafindoPersada.

Sagala, Syaiful. 2009. Administrasi Pendidikan Kontemporer. Bandung: Alfabeta.

Uno, Hamzah. 2012. Teori Kinerja dan Pengukurannya.Jakarta: Bumi Aksara. 